\title{
Causa of Contracts and General Assemblies Resolutions in Polish Cooperative Law
}

(Causa de contratos y resoluciones de asambleas generales en el derecho cooperativo polaco)

\author{
Dominik Bierecki ${ }^{1}$ \\ National Association of Cooperative Savings and Credit Unions \\ Cooperative Research Institute (Poland)
}

Summary: I. Introduction. II. The Requirement of Causa of the Party's Increment. III. Causa of Contracts Regulated by Cooperative Law. IV. Increment as the Consequence of General Assembly Resolution. V. Conclusions.

Sumario: I. Introducción. II. Causa del adquisición. III. Causa de Contratos Regulados por Ley Cooperativa. IV. Adquisición como consecuencia de la resolución de la cooperativa. V. Conclusiones.

Abstract: The article aims to present the manifestations of the requirement of causa of increment under Polish cooperative law. This requirement is one of the fundamental principles of Polish private law. According to this principle, party's increments (acquisition of goods or rights) has to have a valid causa (purpose). Otherwise the party is obligated to return the increment. Because cooperatives are legal persons regulated by private law this requirement fully applies to their legal actions, including cooperative transactions. The requirement of causa also applies to increments provided by the members to the cooperative. Therefore, the requirement of causa is the fundament of cooperative's capital and members' economic participation depends on complying with it.

Keywords: causa, cooperative transactions, cooperative's resolution, members' economic participation

Resumen: El artículo tiene como objetivo presentar las manifestaciones de la causa de los contratos y las resoluciones de las asambleas generales en el derecho cooperativo polaco. El requisito de una causa válida de contratos y resoluciones es uno de los principios fundamentales del derecho privado polaco. Según este principio, los incrementos de las partes (adquisición de bienes o de-

1 Dr. iur., attorney; National Association of Cooperative Savings and Credit Unions; Cooperative Research Institute; Sopot, Poland. Email: d.bierecki@krpj.pl. 
rechos) deben tener una causa (finalidad) válida. De lo contrario, la parte está obligada a devolver el incremento. Dado que las cooperativas son personas jurídicas reguladas por el derecho privado, este principio se aplica plenamente a sus acciones legales, incluidas las transacciones cooperativas (actos cooperativos). Este principio también se aplica a los incrementos proporcionados por los miembros a la cooperativa. Por tanto, el fundamento del capital de la cooperativa y la participación económica de los socios depende del cumplimiento del requisito de causa válida.

Palabras clave: causa, actos cooperativos, resolución de asambleas generales, participación económica de los socios. 


\section{Introduction}

The purpose of the article is to introduce legal character of increment due to contracts and resolutions regulated by Polish cooperative law $^{2}$. Cooperative law in Polish legal system is considered as a special section of private law. All the general provisions on legal actions apply to contracts and resolutions under regulation of cooperative law. Due to a specific purpose of the article, the general provisions on legal actions shall be regarded in relation to analyzed contracts and resolutions regulated by cooperative law ${ }^{3}$.

The concept of causa has a universal application to legal actions providing parties' increment regulated by all parts of private law (not only cooperative law). Yet, undoubtedly, explanation of the requirement of a causa benefits both in theoretical and practical way the

2 In Poland the 16th of September 1982 Cooperative Act's (Official Journal of Laws 2018, item 1245 with further changes) 1st Chapter is a lex generali for all kinds of cooperatives. The regulation of lex specialis character on specific kinds of cooperatives (workers cooperatives and agricultural cooperatives) is included in 2nd Chapter of the 1982 Act and in a number of separate legal acts. These separate acts are:

1. 7th of December 2000 Act on the functioning of cooperative banks, their associations and affiliating banks (Official Journal of Laws 2018, item 613 with further changes),

2. 15th of December 2000 Housing Cooperatives Act (Official Journal of Laws 2018, item 845 with further changes),

3. 27th of April 2006 Social Cooperatives Act (Official Journal of Laws 2018, item 1205 with further changes),

4. 22nd of July 2006 Act on European Cooperative Society (Official Journal of Laws 2018, item 2043 with further changes), which is the implementation of the Council Directive 2003/72/EC of 22 July 2003 supplementing the Statute of a- European Cooperative Society with regard to the involvement of employees (Official Journal of the European Union 18.08.2003, L 207/25),

5. 5th of November 2009 Credit Unions Act (Official Journal of Laws 2019, item 2412 with further changes),

6. 4th of October 2018 Farmers' Cooperatives Act (Official Journal of Laws 2018, item 2037),

7. also the 20th of February 2015 Act on renewable energy sources contains regulation of energy cooperatives (Official Journal of Laws 2018, item 2389 with further changes).

Also, 2nd Chapter of the 1982 Act contains regulation on second tier cooperatives that are: cooperatives' revision associations, cooperatives' economic associations. The regulation on another kind of a second tier cooperative, farmers' cooperatives associations, is also included in the farmers' Cooperatives Act (article 9).

3 In Polish private law, as in German, legal action is a category of legally relevant events which include party's declaration of intent. Legal actions are contracts, resolutions (bilateral legal actions) and unilateral legal actions. Bierć (2018, 587-588). 
studies on cooperative law. From theoretical point of view, it is relevant to explain the application of manifestations of cooperative principles in the system of country's private law not only in the case of its direct implementation. The carried study provides that explanation as in Polish law the application of the requirement of causa is a foundation of cooperative's members economic participation and therefore, the foundation of cooperative capital. From practical point of view, it is relevant to indicate legal provisions applicable to the contracts resulting in legal consequences for cooperatives and their members. Following the concept of causae fulfills that relevance. It allows to identify applicable legal provisions also when their do not refer expressis verbis to cooperatives, their members and contracts between them.

History of the concept of causa dates back to roman law ${ }^{4}$. The requirement of causa of incrementing legal actions was adopted to Polish law on a model of French law which declared as null and void contracts without the causae ${ }^{5}$. However, the concept of causa is not introduced expressis verbis by Polish private law like, for example, in case of Italian law (articles 1325 and 1343 of Codice civile ${ }^{6}$ ). Yet, the majority of Polish legal doctrine as well as case law agrees that Polish private law implicite expresses the requirement of causa of legal actions that effect in the parties' increment. There are different concepts of causa due to it relation to parties' declarations of intent (the concept of subjective causa and the concept of objective causa) and types of legal actions (legal actions that expresses parties' obligations or of solely disposition character). Differences on the concept of causa exist also in comparative law. The interpretation of Polish law on that matter benefits from comparisons to French and German law. Because of that the carried out analyzes includes remarks to these foreign legal systems. However, comparative interpretation of the concept of causa is not the articles purpose. Neither is the introduction of history of the concept of causa. Different concepts of causa and historical remarks are included in the article only to benefit the dogmatic interpretation of Polish law on cooperatives.

4 Bremkamp (2008, 23-143), Lorenzen (1919, 621-646), Van Vliet (2003, 342375). In English common law the concept of causa is represented in the form of doctrine of consideration. Zimmermann $(1996,554)$. The doctrine of consideration exist also in American law. However, the doctrine of consideration evolved as a separate theory and its representatives criticized the concept of causa. Lorenzen (1919, 621646).

5 Smyczyński (1961, 49-50).

6 https://www.brocardi.it/codice-civile/ [access: 2.01.2020]. 


\section{The Requirement of Causa of the Party's Increment}

While identifying incrementing legal actions one should consider whether the party receives the increment from the other party. However, nobody sensible provides an increment to another party without any purpose. This purpose is the causa of the incrementing legal action (accordingly with the subjective concept of the causae) ${ }^{7}$. The causa should be the common purpose in conducting the legal action, not the purpose of the concrete legal action ${ }^{8}$. For example in the contract on sales the causa of the seller is to receive the selling price and the causa of the buyer is to receive a selling good (causa obligandi vel acquirendi). Most often ${ }^{9}$ it is considered that the purpose can be to:

1) acquire a right from the other party, e.g. movable, immovable, or against it, e.g. claim or receivable (in German: Anspruch), i.e. causa obligandi vel acquirendi, when parties' increments are mutual purposes;

2) provide gratuitous increment to the other party (causa donandi);

3) release the party who provides an increment from its obligation, e.g. debt payment (causa solvendi);

4) provide security for liabilities of the party who provides an increment (causa cavendi) ${ }^{10}$;

Also, sometimes a specific kind of causa is distinguished for increment made by paying dividend to the members of a corporation, e.g. cooperative or commercial company (causa societatis) ${ }^{11}$.

This types of causae are the direct purposes of incrementing legal actions (causa proxima). There are also distinguished the indirect purposes of such legal actions (causa remotae), however only the direct purposes should be considered as legally relevant ${ }^{12}$. This relevance

7 Subjective concept of causa is accepted by Czachórski (1952, 36), Grzybowski (1985, 504-506), Pyziak-Szafnicka (1996, 82-89), Wolter, Ignatowicz, Stefaniuk (2001, 270-271). On the other hand, some authors conclude that such a purpose cannot be legally relevant and that causa should be an element of the content of the legal action (objective concept of causae). Drozd (1974, 107), Szlęzak (1995, 116), Szpunar (1997, 107), Radwański $(2008,192)$. Some authors consider the objective concept of causae as a continuation of the German concept of causa which considers it as a foundation of incrementing legal action (Rechtsgrund) but not as its purpose. Gutowski $(2012,353)$.

8 Wolter, Ignatowicz, Stefaniuk (2001, 270-271).

9 Bierć $(2018,637)$.

10 As in the case of fiducia cum creditore contracta. Gołaczyński $(2017,14-15)$.

11 Van Kędzierski $(2018,5,6,17,32,36)$, Wilhelm $(2009,162)$.

12 Grzybowski (1985, 504-506). 
should be reasoned from influence of the causa on validity of increment. Such an influence is regulated by the act and accordingly to Polish law lack of direct purpose results in invalidity of the incrementing legal action and in result in invalidity of the parties' increment. Comparative interpretation provides examples of legal relevance of both direct and indirect causa. Until 2016 such situation existed in French law $^{13}$. Article 1131 of Code Civil stated that the obligation without the causa (la cause), or on a false causa, or on an illicit causa, has no effect. The illicit causa was the one forbidden by law (article 1132 of Code Civil) or contrary to decency or public order (article 1133 of Code Civil). French legal doctrine accepted that legally relevant causa should also exist beyond contractual declarations of intent (indirect causa), not only as a common purpose of the contract (direct causa) ${ }^{14}$. Comparative interpretation between Polish and French law indicates that regardless of repealing a provision of article 1131 of Code Civil requirement of causa of increment still applies in French law. Unlike German law, Polish and French law do not contain a general principle of the abstraction of increment (in German: Abstraktionprinzip) ${ }^{15}$.

The causa is always individual for each of legal action (contract) parties. However, each party should have the same causa, as difference in parties' causa should be considered as lack of consent in their declarations of intent and result in invalidity of the legal action (contract). Also, in some cases the act requires to express the causa in the incrementing contract (requirement of material and formal causality), e.g. sales, donation, and in other cases the incrementing contract is not required to provide such expression (requirement of material causality), e.g. transfer of receivable. ${ }^{16}$

13 Rowan (2017, 805-831), Aynès (2017, 137-143). The relevance of indirect causa was criticized by the representatives of doctrine of consideration as uncertain for contracting parties. Lorenzen (1919, 621-646).

14 Gutowski (2012, 352).

15 Complementing the considerations in the context of the comparative presentation of the principles of increment, it should be noted that in Polish and French law there is no principle of separation between a causa and increment like in German law. Under German law transfer of good requires two contracts: first (Verpflichtungsgeschäft) which creates an obligation and consists causae of the second one (Verfügungsgeschäft) which has a solely disposition character. However, according the principle of separation (Trennungsprinzip) invalidity of the first contract and therefore causa of the second one does not result in invalidity of increment due to the second contract (Abstraktionprinzip). Van Vliet (2003, 376-378, and 2017, 11-14, 2022), Gutowski (2012, 353-354), Sadowski (2014, 237-243).

16 Wolter, Ignatowicz, Stefaniuk $(2001,273)$. 


\section{Causa of Contracts Regulated by Cooperative Law}

Cooperative law in Poland regulates three kind of contracts: contracts between the cooperative and its members which result in conducting by the cooperative business activity in the interests of members (cooperative transactions), contracts between members of transfer of a cooperative share and contracts that result in acquisition of membership in the cooperative ${ }^{17}$.

The scope and detail of cooperative transaction regulation is different depending on the type of contract between the cooperative and the member. In the case of some cooperative transactions the regulation is very specific as in the case of contract on building the flat by the housing cooperative which essential provisions (essentialia negotii) are provided by cooperative law (articles 10 and 18 of $15^{\text {th }}$ of December 2000 Housing Cooperatives Act). In other cases, the regulation is limited to indicating cooperative transactions carried out by cooperative and members. This situation exist in case of members' transactions with credit unions, which are: providing loan or credit, collecting deposits, mediating in concluding insurance contracts (either as insurance agent or insurance broker) and in conducting sell and purchase agreements of investment fund participation units or participation titles of foreign funds and open-end investment funds based in countries belonging to the European Economic Area ${ }^{18}$ (article 3 of $5^{\text {th }}$ of November 2009 Credit Unions Act). This situation also exist in case of workers' cooperatives as the act indicates that members and workers' cooperative should conclude cooperative employment contracts (article 182 of $16^{\text {th }}$ of September 1982 Cooperatives Act). On the other hand, in case of farmers' cooperatives the act simply states that they may perform transactions on sales of agricultural products (article 6 paragraph 2 point 4 of $4^{\text {th }}$ of October 2018 Farmers' Cooperatives Act $)^{19}$.

Very limited regulation is provided on contracts on cooperative shares transfer between members. Under polish law the transfer of cooperative shares is allowed only in the case of farmers' cooperatives

17 On membership in the cooperative see: Bierecki $(2019,29-53)$.

18 Zakrzewski (2014, 38-39).

19 One can wonder whether this approach is specific enough and does it reflects the purpose of the cooperative. However, cooperative transactions are not the only activity of farmers' cooperatives in Polish law. This kind of cooperatives perform also other kinds of activities which are complementary to their cooperative transactions. These other activities fulfill the purpose of produces' cooperative as there are targeted to concentrate demand and supply and plan the production of agricultural products (article 6 paragraph 1 of Farmers' Cooperatives Act). 
and SCEs. Only shares in this type of cooperatives shall be considered as transferable rights, connected with the membership. Shares in other cooperatives are simply a debt or a claim depending on the state of members payment to the cooperative. Cooperative law provides that shares in farmers' cooperatives (article 11 paragraphs 4 and 6 of Farmers' Cooperatives Act) and in SCEs (article 4 paragraph 11 of Council Regulation (EC) No 1435/2003 of 22 July 2003 on the Statute for a European Cooperative Society - SCE) ${ }^{20}$; may be transferred under certain circumstances (which include shares transfer to another member or a person acquiring the membership) but does not indicate what type of contract shall be concluded and thus what kind of causa shall occur ${ }^{21}$. However, in case of transfer of shares in farmers' cooperative the regulation provides also an obligation to conclude a contract with signatures certified by a notary public (article 11 paragraph 7 of Framers' Cooperatives Act).

In case of absence of regulation on cooperative transactions and contracts between members on transfer of cooperative shares general provisions on legal actions apply. This includes provisions on transfer of movables, immovables and claims or receivables which express the requirement of causa of legal actions that effect in the parties' increment (articles 155, 156, 510 of 23 $3^{\text {rd }}$ of April 1964 Civil Code' 22 ). Therefore, these contracts should have one of the indicated causa (obligandi vel acquirendi, donandi, solvendi, cavendi). However, contracts on cooperative transactions which are concluded to conduct business activity by the cooperative in the interests of its members should have an obligandi causa, as its purpose is goods exchange or work performance.

Not only contracts on transfer of movables, immovables and receivables have a causal character. This character also has a contract on building the flat by the housing cooperative, as it results in the obligation of the member to pay for construction costs and in the obligation of the cooperative to build the flat and to establish for the benefit of the member the cooperative right to the premises (flat). Performance of these obligations of the parties of the contract on building the flat by the housing cooperative is secured by parties claims which arise from this contract as the correlate of each party's obligation. Therefore, as this contract lead to parties acquisition of rights (claims) against each other it has the causa obligandi vel acquirendi.

20 Official Journal of the European Union 18.08.2003, L207/1, hereinafter referred to as the SCE's Regulation.

21 Bierecki (2017, 273-280), Bierecki (2019, 80-92).

22 Official Journal of Laws 2019, item 1145 with further changes. 
Also, general provisions on obligation law and specific provisions on types of contracts (e.g. sales, exchange, credit, loan) shall apply to contracts on cooperative transactions. Under these regulations requirement of not just material but also formal causality could apply as in case of contract on sales (article 535 of Civil Code) and exchange (article 603 of Civil Code). Moreover, in case of cooperative employment contract, provisions of $26^{\text {th }}$ of June 1974 Labor Code shall apply without provisions on trial employment contracts and with reservation to provisions of Cooperatives Act (article 199 of Cooperative Act).

Cooperative law provides a specific regulation on contracts that result in acquisition of membership in the cooperative ${ }^{23}$. These are the contracts on founding of the cooperative (article 6 paragraph 1 of Cooperative Act), on admission to the cooperative (art. 16 paragraph 1 and article 17 paragraph 1 of Cooperative Act) and on merger of the cooperatives (article 96 on Cooperatives Act). The purpose (causa) of this contracts should be considered taking into account its result that is creation of private law relationship between the member and the cooperative. Bearing that in mind, one should consider that in the case of concluding the contract on founding of the cooperative the party (cooperative) who provides the increment to the cooperative member does not exist yet. It should be noted that in the case of contract on cooperative foundation, founding members do not oblige against each other. The member's obligation is against the cooperative and exist due to this contract but arise in the moment of cooperative registration. Under Polish law, cooperatives are created and acquire legal personality in the moment of registration by the court (article 11 paragraph 1 of Cooperatives Act ${ }^{24}$. While in this case the founding members do not oblige against each other, neither against the cooperative which does not exist at the moment of concluding the contract, it should be accepted that the contract on founding of the cooperative does not has an incrementing character. Increment due to the legal action has to be made to another its party

At the moment of cooperative registration the membership relationship between the cooperative and the member arises. This relation-

${ }^{23}$ It should be noted that under Polish law, membership should not be identified with cooperative share. In Polish law, membership in the cooperative is a personal right which is not transferable and subject to inheritance. Pietrzykowski $(1990,67)$.

24 On the other hand, in the Netherlands a cooperative is created on the moment the notarial deed has been concluded, and in Germany after submission to the Commercial Register. 
ship has a relative character, which means that the cooperative is in a separate of this kind of private law relationships with each member. From this relationship derive member's obligation to pay cooperative shares (art. 19 paragraph 1 of Cooperatives Act). However, it cannot be stated that the causa of this member's obligation against the cooperative is to acquire membership rights, even though some of them are claims for dividend payment by the cooperative or claims against the cooperative to conclude the contract on cooperative transaction ${ }^{25}$. Membership in the cooperative and therefore, membership rights are acquired by the member due to exercising the freedom of contract in the provided by the act form of general competence to conclude contracts $^{26}$. In cooperative law this general competence derives from the principle of voluntary membership (art. 1 paragraph 1 of Cooperative Act $)^{27}$. When it comes to the membership, this general competence is exercised by voluntary granting rights and receiving obligations by contractual parties. However, a specific case occurs while founding of the cooperative when contracting parties provide rights and obligations to each other but also to a no existing party (cooperative). While performing obligations to pay for cooperative shares the member's purpose is to release himself from the obligation taken by himself against cooperative due to concluding the contract on founding of the cooperative. Therefore, the member provides this increment to the cooperative solvendi causa.

Consequently, it has to be stated that the contract on admission to the cooperative, by a no founding member, arises the member's obligation to pay for cooperative shares and provide increment to the cooperative. This obligation is performed by the acceding member solvendi causa. There is no causae in member's obligation against the cooperative in the form of claims for dividend payment by the cooperative or claims against the cooperative to conclude the contract on cooperative transaction. The contract on admission to the cooperative is concluded by submitting the membership declaration, which is the member's declaration of intent and contains the number of declared shares, and by accepting the submitted declaration by the cooperative (article 16 paragraph 1, article 17 paragraph 1 of Cooperative Act).

In those cases, it should be concluded that the concept of causa is adequate to member's legal actions of solely disposition character

\footnotetext{
25 Zakrzewski $(2014,28)$.

26 Radwański (1977, 33-36, 98).

27 Pietrzykowski $(2012,296)$
} 
(which do not arise obligation to perform) which are the performed payments due to the obligation arisen form contract of founding of the cooperative or contract on admission to the cooperative ${ }^{28}$. This obligation, however, can be terminated by the member by cancellation of declaration of cooperative shares. Cancelation results in creation of the claim for reimbursement of the share (redemption of the share). In this case the cooperative is obligated to return the paid share. However, reimbursement of all member's shares is possible only after termination of the membership in the cooperative (article 21 of Cooperative Act). It should be also noted that member's claims for shares reimbursement are not subject to seizure by cooperative's creditors (article 27 paragraph 5 of Cooperative Act). These provisions reflect the principle of members economic participation, as until membership in the cooperative lasts the member is obligated to participate in cooperative's enterprise with at least one share.

Finally, it should be stated that the third kind of contracts which result in acquisition of membership in the cooperative, i.e. the contracts on merger of the cooperatives (article 96 of Cooperatives Act), does not have an incrementing character and therefore the requirement of the causa does not apply. Cooperative merger is a result of the contract between at least two merging cooperatives. Cooperatives merger results in acquisition of member rights by the members of the incorporated cooperative (in the case of merger per incorporationem) or of cooperatives that merge per unionem (by the formation of a new legal person ${ }^{29}$ ). However, in these cases members are not obligated to pay for cooperative shares. The capital of the incorporated cooperative or merging cooperatives is acquired by the incorporating cooperative or by the cooperative founded by the merger and divided into members shares ${ }^{30}$. Because the contact on merger of the cooperative does not has an incrementing character, and therefore

28 Even more doubts arise when one considers performing a payment not as a legal action (of solely disposition character) but only as a legally relevant act (without parties' declarations of intent). On that matter see: Antas, kukasiewicz (2016, 103120).

29 Cooperatives in Poland can merge per unionem only to create the SCE (article 19 of the SCE's Regulation).

30 In Netherlands members can terminate their membership in case of cooperative merger, split or conversion and execution of this right triggers shares repayment. That is not however the case in Polish law. There is no special right to exit the cooperative and gain shares repayment in this circumstances. Exit from the cooperative may occur on regular basis by membership termination at the time indicated in cooperative bylaws (article 22 of Cooperatives Act). 
the requirement of causa does not apply, one cannot raise charges against the contract on the grounds of division of the shares ${ }^{31}$.

\section{Increment as the Consequence of General Assembly Resolution}

Under cooperative law, the party's increment can also occur as the consequence of the cooperative's resolution. In principle, cooperative should have the management board, the supervisory board and the general assembly consisting of all of cooperative's members. However, on the basis of the act, only resolutions of the general assembly can lead to increment of members or the cooperative ${ }^{32}$. Among others, the general assembly is competent to adopt the resolution on distribution between members the balance surplus (profit) of the cooperative (article 38 paragraph 1 point 4 of Cooperative Act). Adopting this resolution results in acquiring by the members the claims against the cooperative to pay the distributed balance surplus (dividend) and in creation of the cooperative's obligation to perform payments accordingly to the general assembly resolution. While performing this obligation, the cooperative's (legal person) purpose is to be released from the obligation imposed by the general assembly. Therefore, in this case cooperative provides increment solvendi causa. However, as already mentioned (see: point 2 of the article), some authors argue that in this case exists a different kind of purpose, namely causa societatis. It seems that this causa should differ from causa solvendi to be considered as the separate increment purpose. Because causa solvendi occurs while one releases himself from an obligation, taking into account that causa societatis should exist only while providing members of corporation with its profit, this purpose should be to benefit such members.

31 It does not mean however, that this contract cannot be challenged on other grounds, e.g. that cooperatives could not merger with each other (for example in Polish law social cooperatives can merge only with each other but not with a cooperative of other kind).

32 Resolutions of the general assembly or the supervisory board permitting management board to conduct incrementing legal actions are not taken into account. In those cases not the resolutions lead to an increment of the cooperative but legal actions conducted by the management board. In some cases (e.g. buying or selling an immovable by the cooperative) management board actions without permission of supervisory board or general assembly are null and void (articles 38 paragraph 1 point 5 and 46 paragraph 1 point 3 of Cooperatives Act). 
If the cooperative's member has not paid the declared shares, the profit assigned by the general assembly resolution (dividend) is allocated to cover the unpaid shares (article 77 paragraph 3 of Cooperatives Act). However, in this case it cannot be assumed that the member provides an increment to the cooperative. Profit remains the property of the cooperative. A change in the cooperative's balance sheet takes place as the profit is allocated to the shares fund ${ }^{33}$. However, there are situations in Polish cooperative law when due to the general assembly resolution members are obligated to provide increment to the cooperative solvendi causa. This case occurs due to the general assembly resolution on amending the cooperative's bylaws by increasing the number or the value of obligatory declared shares by the member (article 5 paragraph 1 point 3 and article 12a paragraph 1 of Cooperatives Act). In this situation members are obligated to pay additional cooperative shares because of the general assembly resolution ${ }^{34}$. The case when member provides an increment to the cooperative solvendi causa also takes place due to the resolution of the general assembly of the credit union on covering the loss in the balance sheet by obligating members to pay double value of the declared shares ${ }^{35}$. However, this resolution is possible only in case when the credit unions bylaws provide such a possibility of covering the credit unions loss (article 26 paragraph 3 of Credit Unions Act).

Because the cooperative pays its profit to the members solvendi causa, to be released from obligation imposed by the resolution of the general assembly, invalidity of this resolution results in invalidity of the provided increment. Same situation occurs due to invalidity of the resolution of the general assembly obligating cooperative members to pay additional cooperative shares or to pay double value of the declared

33 The shares fund is one of the obligatory funds of the cooperative. It is created by the member's paid shares. The other obligatory fund of the cooperative is the reserve fund created by members' paid cooperative entry fees and by annually allocations of cooperative profit (article 78 paragraph 1 of Cooperative Act). In case of specific kinds of cooperatives, other funds are obligatory (article 78 paragraph 2 of Cooperative Act). For example in case of credit unions an obligatory fund is the savings and loans fund created by the members' additional contributions (article 25 of Credit Unions Act).

34 In the judgement of $17^{\text {th }}$ of June 2015, I CSK 571/14, LEX no. 1771588, Polish Supreme Court indicated that the general assembly resolution is the basis for allocation of profit to cover member's unpaid shares. The resolution is also the basis to increase the value of cooperative shares and members are not required to make the declaration for additional share's value.

35 In the judgement of 12th of December 2019, III CZP 42/19, LEX, no. 2753919, Polish Supreme Court indicated that bankruptcy trustee of the credit union's bankruptcy estate cannot demand from members to pay double value of the declared shares without the general assembly resolution taken prior to the bankruptcy. 
shares. Invalidity of the resolution of the general assembly results in invalidity of the cooperative's or member's obligation to provide increment. In case when profit or shares were paid even due to invalidity of the resolution, cooperative or member can request the return of the provided increment (article 410 paragraph 2 of Civil Code). The invalidity of the resolution of the cooperative's general assembly takes place ex lege in case of its contradiction to the act (article 42 paragraph 2 of Cooperatives Act). The resolution can also be declared as invalid due to repealing it by the court in case of its contradiction with the cooperative's bylaws or with decency or in case when the resolution is against cooperative's or member's interest (article 42 paragraph 3 of Cooperatives Act).

\section{Conclusions}

The requirement of causa of incrementing legal actions is deeply rooted into Polish cooperative law. As mentioned at the beginning, it is the fundament of cooperative's capital and therefore of the cooperative's enterprise. All increments provided to the cooperative by members must have a valid causa. In case of contract on founding of the cooperative and on admission to the cooperative the causa is to be released from the obligation arisen from such a contract (solvendi causa). In case of contracts on cooperative transactions the causa is the benefit provided to the member by the cooperative (causa obligandi vel acquirendi). The requirement of causa is also the fundament of members' economic benefits due to cooperative's business activity as both cooperative transactions and dividend payments has to have a valid causa. Finally, this requirement is also the fundament of members increment due to contracts on transfer of cooperative shares.

\section{References}

AYNĖS, LAURENT. 2017. "The Content of Contracts: Prestation, Object but No Longer la Cause?" In The Code Napoléon Rewritten. French Contract Law after the 2016 Reforms, edited by Joh Cartwright and Simon Whittaker, 137-143. Oxford - Portland, Oregon: Hart Publishing.

BIERECKI, DOMINIK. 2017. Spółdzielnia europejska w świetle prawa polskiego. Sopot: Wydawnictwo Spółdzielczego Instytutu Naukowego.

BIERECKI, DOMINIK. 2019. "The De Lege Ferenda Propositions Regarding the Membership in the Cooperative in Poland". Prawo i Więź, no. 3: 29-53. https://doi.org/10.36128/priw.vi3 
BIERECKI, DOMINIK. 2019. "Zbycie udziału w spółdzielni rolników." Pieniądze i Więź, no. 1: 80-94.

BIERECKI, DOMINIK. 2020. «Estado legal y tendencias de desarrollo de las cooperativas de ahorro y crédito en el derecho polaco y su cumplimiento de las normas WOCCU y los principios cooperativos internacionales». Boletín De La Asociación Internacional De Derecho Cooperativo, n. 56 (abril), 1945. https://doi.org/10.18543/baidc-56-2020pp19-45.

BREMKAMP, TILL. 2008. Causa. Der Zweck als Grundpfeiler des Privatrechts. Berlin: Duncker \& Humblot.

CZACHÓRSKI, WITOLD. 1952. Czynności prawne przyczynowe i oderwane w polskim prawie cywilnym. Warsaw: Państwowe Wydawnictwo Naukowe.

DROZD, EDWARD. 1974. Przeniesienie własności nieruchomości. Cracow: Państwowe Wydawnictwo Naukowe.

GOŁACZYŃSKI, JACEK. 2017. "Dopuszczalność przewłaszczenia na zabezpieczenie z uwzględnieniem nieruchomości." In Zabezpieczenia wierzytelności w prawie polskim w 20-lecie przywrócenia zastawu rejestrowego, edited by Andrzej Jakubecki, Jan Mojak and Jacek Widło, 13-37. Lublin: Innovatio Press Wydawnictwo Naukowe Wyższej Szkoły Ekonomii i Innowacji.

GRZYBOWSKI, STEFAN. 1985. "Czynności prawne. Zasady ogólne". In System prawa cywilnego. Część ogólna 1, 503-511, edited by Stefan Grzybowski. Wrocław - Warsaw - Crakow - Gdańsk - Łódź: Ossolineum and Wydawnictwo Polskiej Akademii Nauk.

GUTOWSKI, MACIEJ. 2012. Nieważność czynności prawnej. Warsaw: C. H. Beck.

LORENZEN, ERNEST G. 1919. "Causa and Consideration in the Law of Contracts." Yale Law Journal, vol. XXVIII, no. 7.

PIETRZYKOWSKI, KRZYSZTOF.1990. Powstanie i ustanie stosunku członkostwa w spółdzielni. Warsaw: Wydawnictwa Uniwersytetu Warszawskiego.

PIETRZYKOWSKI, KRZYSZTOF. 2012. "Prawa rzeczowe do lokali w spółdzielni mieszkaniowej". In System Prawa Prywatnego. Prawo rzeczowe 4, edited by Edward Gniewek, 269-458. Warsaw: C.H. Beck.

PYZIAK-SZAFNICKA, MAŁGORZATA. 1996. Uznanie długu. Warsaw: Wydawnictwa Prawnicze PWN.

RADWAŃSKI, ZBIGNIEW. 1977. Teoria umów. Warsaw: Państwowe Wydawnictwo Naukowe.

RADWAŃSKI, ZBIGNIEW. 2008. "Rodzaje czynności prawnych." In System Prawa Prywatnego, Prawo cywilne - część ogólna 2, edited by Zbigniew Radwański, 173-222. Warsaw: C. H. Beck.

ROWAN, SOLĖNE. 2017. "The new French law of contract." International and Comparative Law Quarterly, vol. 66, no. 4: 805-831. https://doi. org/10.1017/S0020589317000252

SADOWSKI, KORNEL. 2014. "The Abstraction Principle and the Separation Principle in German Law." Przegląd Prawniczy Uniwersytetu im. Adama Mickiewicza, no. 4: 237-243.

SMYCZYŃSKI, TADEUSZ. 1961. "Zagadnienie czynności prawnych abstrakcyjnych w projekcie kodeksu cywilnego", Ruch Prawniczy, Ekonomiczny i Socjologiczny, no. 4: 45-50. 
SZLĘZAK, ANDRZEJ. 1995. "Przewłaszczenie na zabezpieczenie rzeczy przyszłych, rzeczy oznaczonych co do gatunku oraz nieruchomośzi." Rejent, no. 5: 111-130.

SZPUNAR, ADAM. 1997. Zabezpieczenia osobiste wierzytelności. Sopot: Wydawnictwo Prawnicze "Lex".

VAN KĘDZIERSKI, DAWID. 2018. "Geneza zasad ochrony wierzycieli spółek kapitałowych." Transformacje Prawa Prywatnego, no. 1: 5-52.

VAN VLIET, LARS. 2003. "Iusta Causa Traditionis and its History in European Private Law", European Review of Private Law, no. 3: 342-378.

VAN VLIET, LARS. 2017. "Transfer of Property Inter Vivos." In Comparative Property Law: Global Perspectives, Research Handbooks in Comparative Law series, edited by Michele Graziadei and Lionel Smith, 148-170. Cheltenham, UK - Northampton, MA, USA: Edward Elgar Publishing.

WILHELM, JAN. 2009. Kapitalgesellschaftsrecht. Berlin: De Gruyter.

WOLTER, ALEKSANDER, JERZY IGNATOWICZ and KRZYSZTOF STEFANIUK. 2001. Prawo cywilne. Zarys części ogólnej. Warsaw: LexisNexis.

ZAKRZEWSKI, PIOTR et. al. 2014. Spółdzielcze kasy oszczędnościowo - kredytowe. Komentarz. Warsaw: C. H. Beck.

ZIMMERMANN, REINHARD. 1996. The Law of Obligations. Roman Fundations of the Civilian Tradition. Oxford: Oxford University Press. 


\section{Derechos de autor}

El Boletín de la Asociación Internacional de Derecho Cooperativo es una revista de acceso abierto lo que significa que es de libre acceso en su integridad inmediatamente después de la publicación de cada número. Se permite su lectura, la búsqueda, descarga, distribución y reutilización legal en cualquier tipo de soporte sólo para fines no comerciales y según lo previsto por la ley; sin la previa autorización de la Editorial (Universidad de Deusto) o el autor, siempre que la obra original sea debidamente citada (número, año, páginas y DOI si procede) y cualquier cambio en el original esté claramente indicado.

\section{Copyright}

The International Association of Cooperative Law Journal is an Open Access journal which means that it is free for full and immediate access, reading, search, download, distribution, and lawful reuse in any medium only for non-commercial purposes, without prior permission from the Publisher or the author; provided the original work is properly cited and any changes to the original are clearly indicated. 